\title{
Murky Waters
}

\section{Gwen MacGregor}

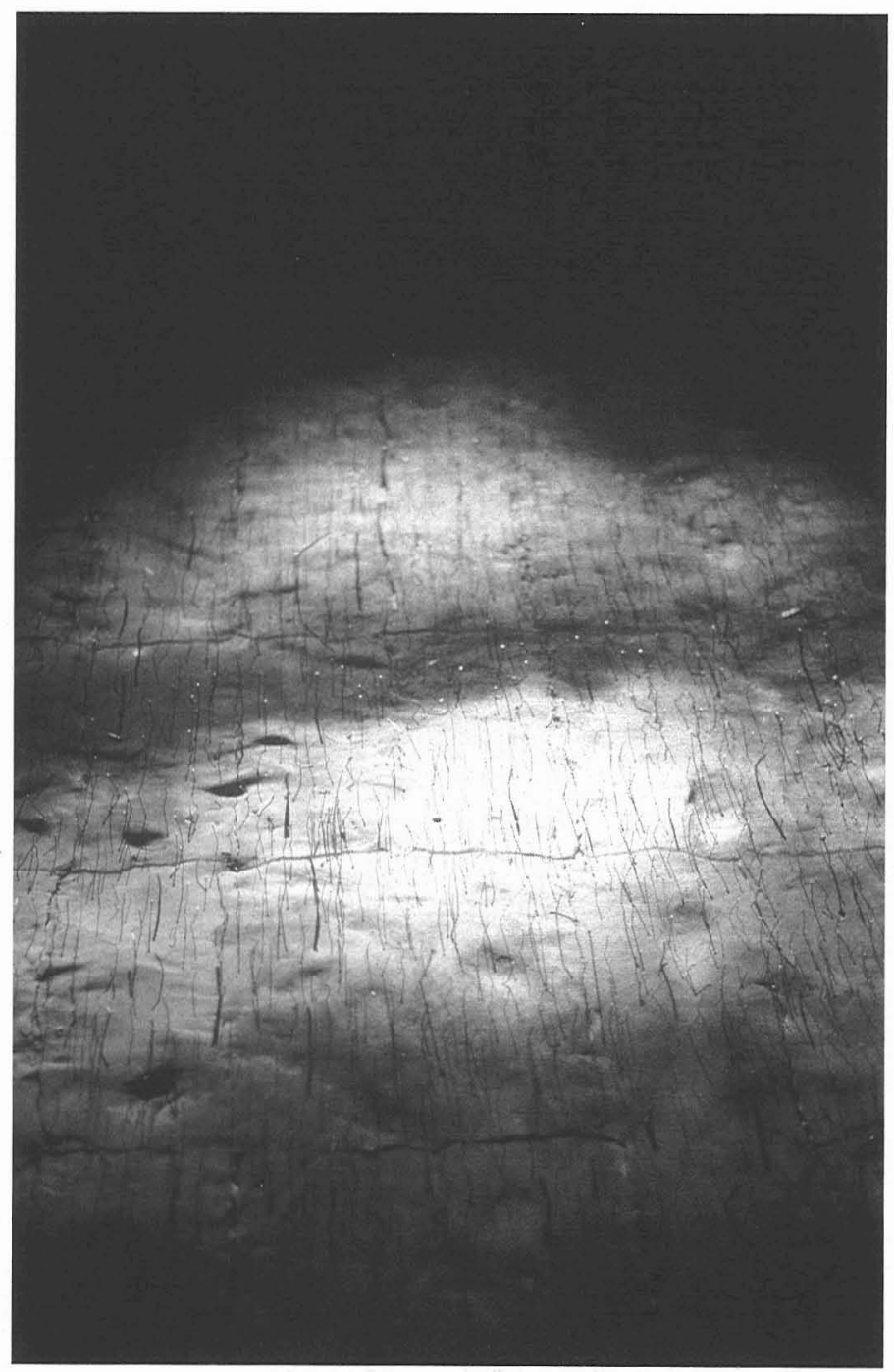

1994,4000 pins on a clay slab, $6^{\prime} \times 4^{\prime} \times 6^{\prime \prime}$ 


\section{Tessera}
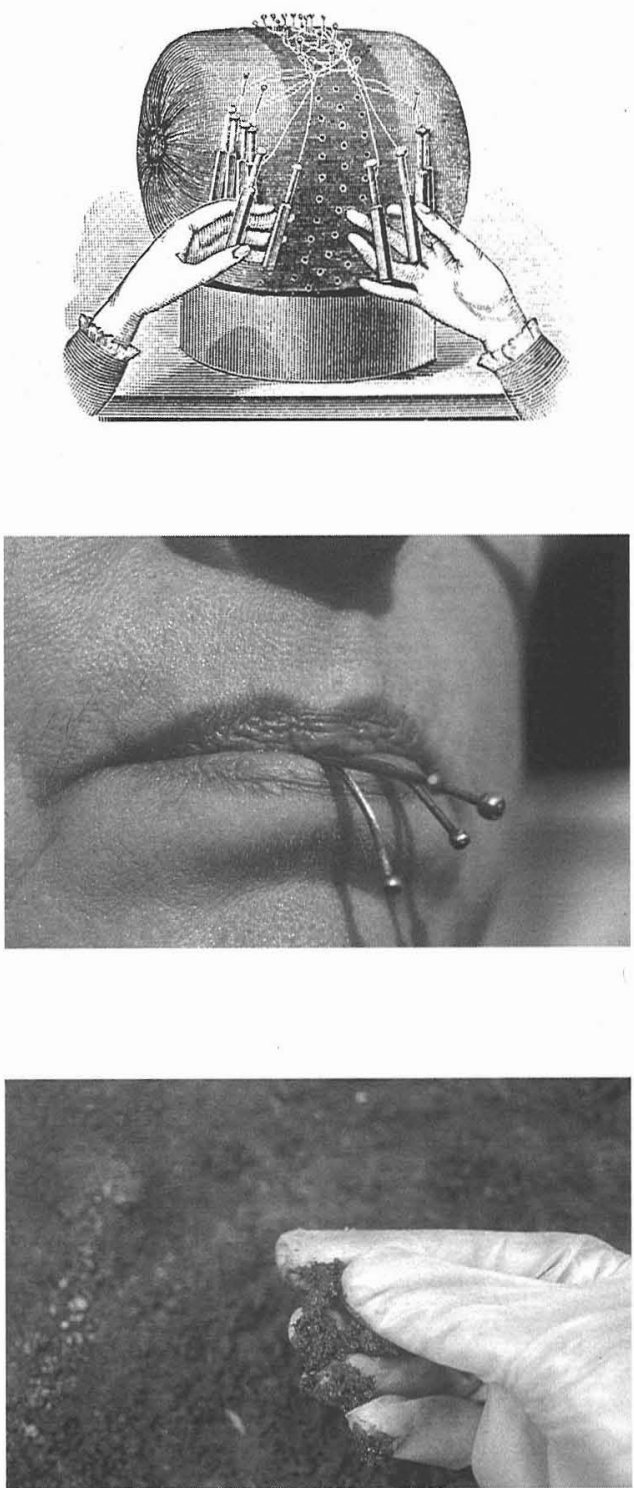

backlit images, $35 \mathrm{~mm} \times 23 \mathrm{~mm}$, embedded in gallery wall 